\title{
The Brazilians in Sydney
}

\section{Cristina Rocha}

Brazil has traditionally been a country that received inflows of migrants. However, in the last two decades of the twentieth century the flow has been reversed. Since the early 1980s, many Brazilians have emigrated, due to a socio-economic crisis that has resulted in massive social inequalities and rampant crime and violence. According to the Brazilian Ministry of Foreign Affairs, four million people have left the country. The largest communities are in the US, Paraguay and Japan.

Since the late 1990s, Australia has become a new and important destination for Brazilians. Brazilian immigration to Australia has had two clear waves. The first migrants arrived in the early 1970s, attracted by an Australian Government assistance scheme. Brazil was undergoing an economic boom but these were poor and unskilled migrants who did not participate in this prosperity. The second group started arriving in the late 1990s. In contrast with the first group, these are young professionals who are highly educated and belong to middle or upper middle classes. They usually migrate individually in search of better quality of life. More often than not, they already speak English and socialise with and marry Australians.

As a result of differences in social class and cultural capital, there is little or no interaction between the early migrants and those who arrived more recently. In Sydney, this clear class divide within the community is a geographical one as well: the earlier group lives in the inner west suburbs, while the more recent group lives at the beach suburbs of Manly, Curl Curl, Dee Why and Bondi. However, once a year in September, the community gets together for the Ritmo Brazilian Festival at Tumbalong Park, Darling Harbour. While singers, dancers and capoeira masters share the stage, Brazilians and Australians mix in the park eating Brazilian food, dancing and chatting.

According to the 2006 census, there were 7,490 Brazilians in Australia, and almost half of them $(3,175)$ lived in Sydney. Although censuses show that the community is increasing (in 2001 there were 4,713 and in 1996 there were 3,359) these numbers are grossly underestimated. For instance, according to the Australian Bureau of Statistics, in 2005 there were 7,100 Brazilian students in Australia. But even this number should be seen as too low. Australian Education International, a government agency, noted that between July 2004 and July 2006, the number of Brazilians on student visas in Australian programmes grew by 109 per cent. According to AEI, Brazil had the potential to become Australia's largest source of international student enrolments outside Asia during 2007. 


\section{Culture and image}

Although it is still small, the Brazilian community is very visible. In recent years, there has been a surge in the popularity of things Brazilian, such as capoeira (martial arts-cum-acrobatics) classes, the all-Australian thongs made in Brazil (Havaianas), power drinks (guaraná and açaí, sold at the fashionable cafes in Paddington and the eastern suburbs), and Brazilian music. In 2007 the Sydney Festival had two special Brazilian Nights and in 2008 it featured a Brazilian Carnival band from Rio. In 2007, a fashionable nightclub and restaurant called Favela opened in Kings Cross, and Brazilian restaurants can also be found in Petersham, Bondi, Leichhardt and Coogee.

Through these practices and commodities, Brazil has acquired a cosmopolitan and exotic image. Media stories have encouraged popular perceptions of Brazil built around a range of clichéd notions - such as sensuality, passion, beauty, vivacity, joie de vivre and sexual freedom-many of which are taken on by Brazilians themselves in strategic ways. ${ }^{1}$ Indeed Brazilian migrants and products are part of the process of commodification, circulation and consumption of the exotic 'other' in Australia. This is so for several reasons. Brazilians still form a small community, come largely from upper middle class urban backgrounds, migrate individually and have mostly a 'young face.' Indeed, their youth and social class contribute to the stereotypical image of cool, party-going, fun-loving, and laid-back people.

Cristina Rocha is an ARC Postdoctoral Fellow at the Centre for Cultural Research, University of Western Sydney

\section{References}

Australian Social Trends 2007: International students in Australia, available at http://www.ausstats.abs.gov.au/ausstats

Australian Education Institute, Market Data Snapshot, October 2006

Cristina Rocha, 'Two Faces of God: Religion and Social Class in the Brazilian Diaspora in Sydney', in PP Kumar (ed), Religious Pluralism in the Diaspora, Brill, Leiden, 2006

\section{Endnotes}

${ }^{1}$ See Nicolette Burke, 'When My Baby Smiles at Me I Go to Rio, or Bondi', Daily Telegraph, 17 March 2004, p 24; 'Cleo in Rio' Cleo, December 2004, pp 96-104; Jane Cornwell, 'The Whole World Is Going Brazilian', Sydney Morning Herald, 20-21 December 2003, p 19; George O Miller, 'Hit Parades: With Its Spectacular Beaches and Sensual Bossa Nova, Rio Loves to Show Off', Sydney Morning Herald, 13-14 March 2004, pp 2-3 and Bernard O'Shea, 'If Rio is Grand, Brazil's Nuts', The Australian Financial Review, 5-7 January 2007, pp L 8-9. 